\title{
FORMALNE REGULACJE ZATRUDNIENIA A PERSPEKTYWA RÓŻNORODNOŚCI KAPITALIZMU*
}

\section{WPROWADZENIE}

W porównawczych badaniach nad kapitalizmem szczególną wagę przykłada się do sposobu ukształtowania relacji między pracownikami a pracodawcami. Instytucjonalne ramy rynku pracy obejmują szereg zagadnień formalnych i nieformalnych, między innymi takich jak: dopuszczalne formy świadczenia pracy; regulacje odnoszące się do wynagrodzeń; uprawnienia i siłę przetargową pracodawców oraz pracowników, w szczególności funkcjonowanie organizacji pracodawców oraz związków zawodowych; aktywne i pasywne polityki rynku pracy; kulturę, zwyczaje i nastawienie do pracy.

Od czasu publikacji kluczowego artykułu Petera A. Halla i Davida Soskice'a ${ }^{1}$ perspektywa różnorodności kapitalizmu (varieties of capitalism - VoC) zdobyła dużą popularność i stała się niemal paradygmatycznym punktem odniesienia w porównawczych badaniach nad gospodarkami. Podejście VoC jest rozwijane przez socjologów, ekonomistów i politologów i koncentruje się na porównywaniu modeli ekonomicznych pod względem roli, jakie pełnią w nich instytucje, a także efektywności gospodarczej. Ujęcie VoC powstało jako konkurencja wobec teorii konwergencji: badaczy łączy przekonanie, że nie istnieje jeden efektywny model ukształtowania gospodarczego państw. Kluczową rolę w rozważaniach odgrywa pojęcie komplementarności instytucjonalnej, opisujące powiązania między konkretnymi elementami systemu instytucjonalnego pod kątem korzyści ekonomicznych, jakie przynoszą w danych systemach ${ }^{2}$. Istnieją różne możliwości funkcjonowania instytucji oraz powstałych komplementarności i wreszcie różne, indywidualne przewagi powstałych w ten sposób modeli (wariantów) gospodarczych. Badacze wykorzystujacy ujęcie VoC zwykle posługują się typologiami, grupując państwa w modele o zbliżonych cechach.

W ostatnich latach coraz głośniej podkreśla się ograniczenia VoC, niemniej perspektywa ta pozostaje ciągle jedną z najczęściej stosowanych w porów-

* Artykuł powstał w ramach projektu „Polityka prawa pracy po początku kryzysu ekonomicznego w Polsce. Segmentacja rynku pracy i naruszenia prawa pracy”. Projekt został sfinansowany ze środków Narodowego Centrum Nauki (UMO-2015/19/N/HS5/01227).

${ }^{1}$ Hall, Soskice (2001).

2 Jasiecki (2014): 48. 
nawczych badaniach nad gospodarkami ${ }^{3}$. Krytyka koncepcji dotyczyła przede wszystkim nadmiernej statyczności założeń i tendencji do zbyt daleko idacych uproszczeń, które miały bagatelizować rzeczywiste zróżnicowanie gospoda$r^{4} k^{4}$. W szczególności odmienne reakcje gospodarek na kryzys ekonomiczny przyczyniły się do zrewidowania stanowisk, nawet wśród głównych przedstawicieli podejścia ${ }^{5}$.

Artykuł ma na celu opisanie roli, jaka w podejściu VoC przypisywana jest formalnym regulacjom odnoszącym się do zatrudnienia (dalej także: „prawu pracy") w porządkach gospodarek instytucjonalnych. Jednym z założeń nowego instytucjonalizmu, podzielanym przez badaczy z nurtu VoC, jest przekonanie, że zachowania aktorów społecznych nie są kształtowane wyłącznie przez formalnie rozumiany system prawny, ale także przez nieformalne zasady, zwyczaje i praktyki ${ }^{6}$. Od samych początków VoC jako metody analizy porównawczej współczesnego kapitalizmu pojawiały się głosy, że zagadnienie formalnych ram instytucjonalnych rynku pracy często umykało socjologicznie i politologicznie zorientowanym badaczom ${ }^{7}$. Jednocześnie współczesne rynki pracy sa poddane licznym regulacjom prawa stanowionego, które obejmuja zarówno indywidualne, jak i zbiorowe stosunki pracy. Spróbuję także udowodnić, że przyjrzenie się, w jaki sposób nurt VoC problematyzuje prawo pracy, mówi nam również coś więcej na temat samych porównawczych badań nad gospodarkami. Sposób analizy elementów instytucjonalnych silnie zależy do tego, jak rozumie się rolę formalnych instytucji w kapitalizmie.

W pierwszej kolejności zostanie dokonany przegląd literatury z nurtu VoC pod katem roli prawa pracy $\mathrm{w}$ typologiach oraz propozycjach różnych badaczy. Choć umiejscowienie prawa pracy w ujęciach badaczy z nurtu VoC jest oczywiście zróżnicowane, to wykazuje spójności wynikające z odmiennych perspektyw badawczych. Pierwsza grupa badaczy marginalizuje zagadnienie formalnych regulacji zatrudnienia. Wynika to albo z koncentracji badaczy na większych jednostkach analizy, albo z silnie empirycznego zorientowania metodologicznego w warunkach braku danych i wskaźników dotyczących formalnych regulacji zatrudnienia. Po drugie, część badaczy szczególnie skoncentrowanych na aspekcie porównawczym postrzega regulacje zatrudnienia przez pryzmat funkcji, jakie pełnią w poszczególnych gospodarkach. Wyróżnia się tu dwa stanowiska. Badacze bliżsi teoriom racjonalnego wyboru i oryginalnego ujęcia Halla i Soskice'a, bardziej skoncentrowani na problemie koordynacji działań przez aktorów gospodarczych, traktuja prawo pracy jako jedno z narzędzi koordynacji ekonomicznej. Badacze skupieni na zagadnieniu spójności społecznej oraz głębiej integrujący tematykę państwa dobrobytu w swoje typologie traktuja prawo pracy jako instrument ochronny alternatywny względem welfare state. Wreszcie, trzecia grupa badaczy skoncentrowanych na dynamice

\footnotetext{
${ }^{3}$ Coates (2015): 11-27; Streeck (2009); (2011).

${ }^{4}$ Deeg, Jackson (2006).

5 Soskice (2009); Thelen (2014).

${ }^{6}$ Hall, Soskice (2001): 12 n.; Hall, Thelen (2009): 9-10.

7 Freeman (2005); Michelotti, Nyland (2008); Dibben, Williams (2012).
} 
instytucjonalnej opisuje zmiany w regulacjach zatrudnienia w kontekście głębokich reform lub korekt systemów instytucjonalnych poszczególnych państw.

We wnioskach i podsumowaniu przyjrzę się zróżnicowaniu ujęć, szerzej argumentując, że różnice w stanowiskach są rezultatem odmiennego sposobu rozumienia samego pojęcia kapitalizmu i roli odgrywanej w nim przez system instytucjonalny. Podkreślanie ekonomicznej funkcji regulacji zatrudnienia wynika z postrzegania kapitalizmu jako systemu przede wszystkim gospodarczego w ścisłym tego słowa rozumieniu. Natomiast badacze skoncentrowani na ochronnej funkcji regulacji zatrudnienia traktują kapitalizm jako system społeczno-gospodarczy, dla którego funkcjonowania niezbędne jest wprowadzanie do systemu instytucjonalnego odmiennych od rynkowych zasad wymiany.

\section{MARGINALIZACJA ZAGADNIENIA FORMALNYCH REGULACJI ZATRUDNIENIA Z PERSPEKTYWY VoC}

Wielu badaczy posługujących się perspektywą VoC marginalizuje problem funkcji i funkcjonowania formalnych regulacji zatrudnienia. Przyczyny tego stanu rzeczy są zasadniczo dwojakie. Po pierwsze, część badaczy koncentruje się na różnicach w szeroko rozumianych stosunkach przemysłowych ${ }^{8}$, tj. odmiennościach $\mathrm{w}$ relacjach między pracownikami a pracodawcami, wynikających z różnych mechanizmów koordynacyjnych zwiąanych z: dominujacymi w gospodarce branżami (silny sektor przemysłowy w gospodarce oznacza co innego dla stosunków między pracodawcami a pracownikami niż dominacja sektora usługowego), sposobami organizacji pracy, siłą przetargową (np. rola i pozycją związków zawodowych) oraz zwyczajami funkcjonujaccymi na rynku pracy (np. modelu „zatrudnienia na całe życie”, kultury „hire and fire” itd.). Koncentracja na stosunkach przemysłowych wynika zarówno z intelektualnych korzeni VoC (ekonomii politycznej ${ }^{9}$ ), jak i tendencji badaczy do dokonywania holistycznych analiz instytucji rozumianych jako sploty reguł formalnych oraz nieformalnych zachowań. W takiej sytuacji łatwo o zepchnięcie na margines roli formalnego prawa oraz skoncentrowanie się na ustrukturyzowanych praktykach aktorów.

Dobrego przykładu na marginalizację formalnych regulacji zatrudnienia dostarcza wpływowa typologia Davida Coatesa, dzielacca gospodarki według sposobu finansowania przedsiębiorstw oraz strategii konkurencyjnych przedsiębiorstw na kapitalizm oparty na rynku (marked-led), kierowany przez państwo (state-led) oraz oparty na negocjacjach czy konsensusie (negotiatedl consensual ${ }^{10}$. Dla firm w gospodarkach opartych na rynku (do których należy np. Wielka Brytania) kluczowa jest możliwość eksplorowania nowych

\footnotetext{
8 Crouch (2005): 47.

${ }^{9}$ Hall, Soskice (2001): 2-6 - proponują własną typologizację swoich inspiracji teoretycznych.

${ }^{10}$ Coates (2000): 9-10; tłumaczenie pojęć za: Wojtyna (2005): 14-15.
} 
nisz rynkowych i konkurencyjność produktowa. Formalne regulacje zatrudnienia zakładają bardzo ograniczoną ochronę pracownika, która kształtowana jest w drodze indywidualnych negocjacji z pracodawca. W gospodarkach kierowanych przez państwo (obejmujacych gospodarki z silną rolą państwa, takie jak np. Japonia) regulacje rynku pracy powstają w toku negocjacji między kluczowymi firmami a odpowiednimi rządowymi agencjami, ale ochrona stosunku pracy jest niejako pochodna strategii wynikających z praktyk poszczególnych firm ${ }^{11}$. Wreszcie, w gospodarkach opartych na negocjacjach (do których należą np. Niemcy) regulacje (które moglibyśmy nazwać zbiorowym prawem pracy) instytucjonalizują proces współuczestniczenia pracowników w zarządzaniu firmami. Ochrona stabilności zatrudnienia indywidualnych pracowników jest pochodną strategii firm, które są wypracowywane w porozumieniu z nimi. Założenie jest więc następujące: gdy związki zawodowe są silne, zmusza to pracodawców do negocjowania i uwzględniania interesów pracowników. Negocjacje te prowadzą między innymi do zawierania umów zbiorowych, ustalających poziom ochrony pracowników, wynagrodzenia minimalne na poziomie ogólnokrajowym, sektorowym lub branżowym itd. W takiej sytuacji stanowione prawo pracy jest właściwie niepotrzebne, a ustawowa ochrona zatrudnienia istnieje w formie rezydualnej, ponieważ jest i tak wypierana przez ustalenia negocjacji zbiorowych. Słabe związki zawodowe i wąsko zakreślony system negocjacji zbiorowych oznaczają słabość reprezentacji interesów pracowniczych, co przekłada się na znikomy poziom ochrony zapewniany przez prawo pracy.

Logika zastosowana przez Coatesa prowadzi do paradoksalnego wniosku. W państwach, w których pracownicy są dobrze zorganizowani, regulacje prawa stanowionego chroniące pracowników są niepotrzebne, ponieważ, z jednej strony, ograniczaja zakres ewentualnych negocjacji zbiorowych, natomiast z drugiej - pracownicy i tak sobie poradzą dzięki korzystnym rozwiązaniom wynegocjowanym przez związki zawodowe. Formalne regulacje zatrudnienia są również bardzo ograniczone w państwach o słabych związkach zawodowych, ponieważ w takiej sytuacji nie ma podmiotu starajaccego się o to, aby regulacje chroniły pracowników. Pracownikom pozostaje więc negocjowanie poziomu swojej ochrony przez indywidualne ustalenia z pracodawca.

Druga przyczyna marginalizacji zagadnienia formalnych regulacji zatrudnienia jest związana $\mathrm{z}$ porównawczym aspektem perspektywy VoC. Pozwalające na porównania dane dotyczące szeroko rozumianych stosunków przemysłowych (stopień uzwiąkowienia, poziom krycia przez umowy zbiorowe, wskaźniki uczestnictwa pracowników w zarządzaniu firma) są powszechnie dostępne i są wykorzystywane w, najczęściej służących do tworzenia typologii w nurcie $\mathrm{VoC}$, analizach klastrowych ${ }^{12}$. Analogicznych, nadających się do porównań, danych i wskaźników odnoszących się do stopnia korzystania z prawa lub poziomu ochrony prawnej jest znacznie mniej: ograniczają się do stop-

11 Coates (2000): 131.

12 Np.: Witt, Jackson (2016); Hall, Gingerich (2009); Maszczyk (2015); Próchniak et al. (2016). 
nia korzystania z umów niestandardowych oraz syntetycznych wskaźników sztywności zatrudnienia ${ }^{13}$. Częściowo wynika to z niewielkiej liczby wskaźników prawniczych (legal indicators), na którą zwraca się uwagę w literaturze ${ }^{14}$.

\section{FUNKCJONALNE ROZUMIENIE REGULACJI ZATRUDNIENIA: REGULACJE ZATRUDNIENIA JAKO NARZĘDZIE KOORDYNACJI EKONOMICZNEJ}

Część badaczy posługujących się perspektywą VoC analizuje regulacje zatrudnienia pod kątem funkcji ekonomicznej i rozwiązywania problemów związanych z koordynacją gospodarcza, zależnych od ułożenia pozostałych instytucji w poszczególnych wariantach instytucjonalnych. Kształt regulacji zatrudnienia interpretuje się przez funkcjonalne wymogi systemu gospodarczego. Ten sposób postrzegania regulacji zatrudnienia (i prawa w ogóle) jest zbieżny z interpretacjami odwołujaccymi się do funkcjonalizmu i teorii racjonalnego wyboru ${ }^{15}$. Regulacje powstają i są kształtowane w taki sposób, aby służyć konkretnemu ekonomicznemu celowi. Może być to obniżenie kosztów transakcyjnych (jak w analizie kosztów transakcyjnych ${ }^{16}$ ), eksploatacja ekonomiczna (w marksizmie ${ }^{17}$ ) czy reprodukowanie określonego sposobu akumulacji kapitału (jak w ważnej dla perspektywy VoC francuskiej szkole regulacyjnej ${ }^{18}$ ).

$\mathrm{Na}$ analizie tego, jak instytucje zachęcają do określonego rodzaju koordynacji ekonomicznej, jest skoncentrowana typologia systemów biznesowych Richarda Whitleya ${ }^{19}$. W zakresie stosunków pracy Whitley analizuje „systemy pracy” (work systems), które rozumie jako różnice w sposobie jej organizacji, wynagradzania, sprawowania kontroli, relacji w miejscu pracy oraz ukształtowania polityk związanych z zatrudnieniem, w szczególności zaś szkoleń zawodowych $^{20}$. W gospodarkach silnie konkurencyjnych, gdzie wymagana jest duża elastyczność rynku pracy, formalne regulacje tworza minimalne ramy współpracy pracowników z pracodawcami, między którymi panują konfliktowe relacje i którym brakuje alternatywnego mechanizmu koordynacji w postaci zaufania ${ }^{21}$. Natomiast w gospodarkach koordynowanych reguły formalne na rynku pracy (w szczególności: zbiorowe prawo pracy) uniemożliwiaja szybkie zwalnianie i zatrudnianie, co zmusza pracodawców i pracowników do bardziej kooperacyjnego podejścia i wypracowywania długofalowych polityk zwiększających produktywność (przede wszystkim systemów szkolnictwa za-

13 Amable (2003): 125-128.

14 Restrepo Amariles (2015).

15 Oryginalne ujęcie Halla i Soskice’a uważane jest za mieszające perspektywę racjonalnego wyboru z historycznym instytucjonalizmem - zob. Katznelson, Weingast (2005).

16 Williamson (1975).

17 Screpanti (2017).

18 Boyer (1979); (2005).

19 Whitley (1999); (2007).

20 Whitley (1999): 90

21 Whitley (1999): 54. 
wodowego) ${ }^{22}$. U Whitleya formalne regulacje zatrudnienia pełnią funkcję koordynacyjna w obu wariantach - w gospodarkach konkurencyjnych narzucaja minimalne zasady współpracy pracodawców z pracownikami, natomiast w gospodarkach koordynowanych - budują formalne ramy funkcjonowania zaufania jako podstawy współdziałania.

Regulacje jako instrument koordynacji ekonomicznej opisuje również kluczowy dla nurtu VoC artykuł Halla i Soskice'a. Ciężar analizy przesunięty jest na sfery, w których firmy muszą rozwiązywać swoje problemy koordynacyjne ${ }^{23}$ : stosunki przemysłowe, szkolenia zawodowe i edukacja, ład korporacyjny, stosunki między firmami oraz relacje z pracownikami (rozumiane jako kompetencje i mechanizmy współpracy). Centralną kwestią jest w nim sposób kształtowania umiejętności pracowników ${ }^{24}$. Ze względu na to, że dla przewagi komparatywnej koordynowanych gospodarek rynkowych niezbędne jest nabywanie wiedzy ściśle wyspecjalizowanej (zwykle potrzebnej jednemu sektorowi czy wręcz jednej firmie) w ramach szkoleń zawodowych, gospodarki te budują szereg instytucji mających na celu zwiększenie stabilności zatrudnienia. Wynika to z potrzeby stworzenia pracownikom takich warunków, aby nie obawiali się nabywać ściśle specyficznych umiejętności (które trudno byłoby wykorzystać w innych firmach lub sektorach) oraz z chęci zabezpieczenia się przez pracodawców ponoszących nakłady finansowe na szkolenia zawodowe. Współpraca w koordynowanych gospodarkach rynkowych opiera się więc na niesformalizowanym zaufaniu między stronami, aby zwiększyć perspektywę czasową obu stron stosunku pracy. Osiaga się to z jednej strony przez instytucje zwiększające ochronę pracownika przed zwolnieniem i zwiększające stabilność jego pracy, z drugiej przez regulacje instytucjonalizujące wpływ pracowników na działanie tej firmy (reprezentacja pracownicza, rady pracownicze).

Przeciwnie, efektywność liberalnych gospodarek rynkowych jest zależna od pracowników posiadających wykształcenie ogólne, często o profilu uniwersyteckim. Gospodarki te potrzebuja silnie mobilnego rynku pracy, pozwalającego „podbierać” pracowników konkurencji oraz dużej swobody w przebudowywaniu modelu biznesowego umożliwiającej wchodzenie $\mathrm{w}$ nowe, innowacyjne nisze. $\mathrm{Z}$ tego względu regulacje zatrudnienia sa bardzo elastyczne i dają pracodawcom dużą swobodę zwalniania i zatrudniania, a relacja pracowników z pracodawcami jest formalizowana przez kontrakty, których treść jest względnie swobodnie kształtowana w procesie negocjacji ${ }^{25}$.

$\mathrm{W}$ rezultacie $\mathrm{w}$ obu modelach oddziaływanie formalnych regulacji jest ograniczone. W przypadku liberalnych gospodarek rynkowych formalne regulacje zatrudnienia muszą być bardzo elastyczne, natomiast w przypadku koordynowanych gospodarek rynkowych reguły formalne nie mają dużego

\footnotetext{
${ }^{22}$ Whitley (2007): $209 \mathrm{n}$.

${ }^{23}$ Hall, Soskice (2001): 6-7.

24 Martin (2014): 65-85.

25 Hall, Soskice (2001): 29-32.
} 
znaczenia, ponieważ koordynacja ta odbywa się przede wszystkim nieformalnie, przy niewielkim udziale reguł formalnych ${ }^{26}$.

Badacze silnie nawiązujący do oryginalnego ujęcia Halla i Soskice'a podkreślają właśnie koordynacyjny charakter formalnych regulacji zatrudnienia, najczęściej silnie związany z zagadnieniem kształcenia umiejętności potrzebnych do wzrostów produktywności w konkretnych wariantach gospodarczych ${ }^{27}$. Podaje się jednak również inne argumenty, np.: zgodność kształtu regulacji ze strategiami firm ${ }^{28}$ czy też konieczność istnienia komplementarności między liberalnym (sztywnym) rynkiem produktowym a liberalnym (sztywnym) rynkiem pracy, wynikające ze sposobu, w jaki formalna regulacja tych rynków wpływa na motywacje przedsiębiorców i zmusza ich do odmiennej formy koordynacji zarówno z pracownikami, jak i z innymi firmami ${ }^{29}$.

\section{FUNKCJONALNE ROZUMIENIE REGULACJI ZATRUDNIENIA: REGULACJE ZATRUDNIENIA JAKO INSTRUMENT OCHRONNY}

Druga grupa badaczy wykorzystująca perspektywę VoC postrzega formalne regulacje zatrudnienia jako alternatywny lub uzupełniajaccy instrument ochronny pracowników względem klasycznych narzędzi państwa dobrobytu (takich jak np. transfery socjalne). W tym ujęciu formalne regulacje zatrudnienia mogą mieć pewne funkcje ekonomiczne (podobnie jak np. państwo dobrobytu może zwiększać efektywność ekonomiczna, napędzając popyt), natomiast postrzega się je przede wszystkim jako korygujące wymianę rynkową instytucje ochronne zgodne z ,gospodarką moralną" społeczeństwa ${ }^{30}$.

Przykładu na tego rodzaju rozumienie prawa pracy dostarcza bardzo wpływowa wśród badaczy wykorzystujących perspektywę VoC typologia Bruno Amable'a. Opiera się ona na analizie natury rynków produktowych, rynków pracy, rodzaju finansowania i kształtu państwa dobrobytu. Gospodarki rynkowe (market-based economies) bazują na silnej konkurencji produktowej wymagajaccej dużej elastyczności pracowników, która zapewniana jest przez elastyczne regulacje zatrudnienia oraz rezydualne państwo dobrobytu. Instrumenty welfare state sa ograniczone, a ochrona zatrudnienia niska - z krótkimi okresami wypowiedzenia, ograniczona ochrona zatrudnienia, łatwymi i tanimi procedurami zwolnień, rozbudowanymi możliwościami zatrudniania na próbę, niewielką koordynacją negocjacji płacowych i dużą elastycznością wy-

${ }^{26}$ Hall i Soskice do pewnego stopnia odeszli od wcześniej powszechnego stanowiska podkreślającego kluczową rolę formalnych instytucji zatrudnienia w ograniczaniu ryzyka moralnego i wydłużaniu perspektyw czasowych aktorów gospodarczych; zob. np. Marsden (1999): 33 n.; $164 \mathrm{n}$.

${ }^{27}$ Schmidt (2002): 142-146 - choć amerykańska badaczka nieco dystansuje się od ,firmocentrycznego" podejścia Halla i Soskice'a, to jej typologia silnie do niego nawiązuje, niemniej dokłada kilka dodatkowych zmiennych. Zob. także: Jackson, Deeg (2008); Thelen (2004); oraz Hall, Gingerich (2009): 462, którzy również koncentrują się na koordynacyjnej funkcji regulacji zatrudnienia, choć klasyfikuja bariery zwalniania pracowników jako regulacje ochronne.

${ }^{28}$ Nölke, Vliegenthart (2009): 678-679.

${ }^{29}$ Becker (2009): $67 \mathrm{n}$.

${ }^{30}$ Thompson (1971); Streeck (2015): 4-5. 
nagrodzeń. Produkty, w których specjalizują się państwa opisywane jako reprezentujące model socjaldemokratyczny (social-democratic), wymagają nabywania specjalistycznych umiejętności przez pracowników przez dłuższy czas. Model jest jednak poddany silnej presji konkurencyjnej, w związku z czym opiera się na średniej elastyczności prawa oraz rozwiniętym państwie dobrobytu, w tym rozbudowanych aktywnych politykach rynku pracy. Mechanizmy zabezpieczenia socjalnego oraz silne związki zawodowe niejako buforują elastyczność regulacji formalnych ${ }^{31}$.

Kontynentalno-europejski kapitalizm (continental European capitalism) jest dość podobny do socjaldemokratycznego w tym sensie, że łączy rozbudowane państwo dobrobytu ze średnim poziomem ochrony zatrudnienia. Elastyczność rynku pracy jest jednak mniejsza i bardziej niż w modelu socjaldemokratycznym chroniona pasywnymi mechanizmami. Powoduje to również dualizację rynku pracy, tj. powstawanie sektora pracowników, których poziom ochrony jest znacznie niższy.

W wariancie kapitalizmu południowoeuropejskiego (South European capitalism) konkurencja produktowa jest z kolei mniejsza, ochrona pracowników zaś zapewniana jest przede wszystkim przez rozbudowane regulacje formalne i w mniejszym stopniu opiera się na instrumentach państwa dobrobytu. Presja konkurencyjna powoduje natomiast przede wszystkim dualizację rynku pracy.

Model azjatycki kapitalizmu (Asian capitalism) również opiera się na długotrwałych relacjach między pracodawcami a pracownikami. Wariant ten ma bardzo słabo rozbudowane welfare state, ale opiera się na specyficznie sztywnych rynkach pracy, w których pracownicy są silnie chronieni, jednakże ochrona ta jest zapewniana nie przez formalne regulacje, ale przez wkomponowanie stabilności zatrudnienia $\mathrm{w}$ strategie firm $^{32}$. Typologia Amable'a koncentruje się więc na ochronnej funkcji formalnych regulacji zatrudnienia, traktowanej jako alternatywa lub uzupełnienie państwa dobrobytu. Funkcję koordynacyjną w relacjach pracodawca-pracownik przejmują niejako polityki rynku pracy oraz dialog społeczny.

Z podobnych założeń wychodzi typologia Bernarda Ebbinghausa, oparta na różnicach w ukształtowaniu komplementarności między sferami protekcji, produkcji i partnerstwa (protection, production, partnership), czyli sposobem działania welfare state, regulacją rynku produktowego oraz rynku pracy. Dla Ebbinghausa ukształtowanie formalnych regulacji zatrudnienia oraz instrumenty państwa dobrobytu są zależne od siebie w tym sensie, że określony kształt instrumentów socjalnych wpływa na kształt formalnych regulacji zatrudnienia - i na odwrót. Sfery są analizowane pod kątem realizacji funkcji ochronnej ${ }^{33}$. Tego typu ujęcie jest szczególnie często reprezentowane przez badaczy łączących perspektywę VoC z analizami dotyczącymi państwa dobrobytu ${ }^{34}$.

\footnotetext{
31 Amable (2003): 109.

32 Amable (2003): 104-106.

33 Ebbinghaus (2006): 58-62, 84.

${ }^{34}$ Korpi (2006); Emmenegger (2011).
} 


\section{FORMALNE REGULACJE ZATRUDNIENIA A ZAGADNIENIE ZMIANY INSTYTUCJONALNEJ W PERSPEKTYWIE VoC}

Bardzo wcześnie badacze wykorzystujacy perspektywę VoC zauważyli, że założenia badawcze Halla i Soskice’a wyrażone w artykule z 2001 r. mają pewne „konserwatywne skrzywienie”35. Krytykując hipotezę o konwergencji, Hall i Soskice argumentowali, że nie ma podstaw do twierdzeń, że koordynowane gospodarki rynkowe upodobnią się do liberalnych. Presje rynkowe miały nie zmieniać podstawowych orientacji ekonomicznych aktorów gospodarczych. Instytucje były ze sobą zsynchronizowane w ten sposób, że koordynowane gospodarki były efektywniejsze w pewnym aspekcie produkcji niż liberalne. Prowadziło to do wniosku o swoistej równowadze instytucjonalnej obu modeli i ograniczonej podatności na zmiany. Podobne stanowiska głoszące tezy o zasadniczej stabilności instytucjonalnej wyrażała bliska VoC literatura dotyczaca redukowania welfare state, podkreślająca w szczególności względną stałość w politykach społecznych oraz kluczowe dla państwa dobrobytu znaczenie mechanizmów „zależności od ścieżki” (path dependency) ${ }^{36}$.

Wprowadzenie opisów dynamicznej zmiany instytucjonalnej do perspektywy VoC wymagało rozwoju teorii ${ }^{37}$. Biorac pod uwagę dotychczasowe ustalenia, zmiany instytucjonalne opisywane przez badaczy wykorzystujacych perspektywę VoC w zakresie formalnych regulacji zatrudnienia można podzielić dwojako, a punktem różnicującym jest zakres spójności zmiany instytucjonalnej z szerzej identyfikowanymi cechami modelu gospodarczego.

Po pierwsze, zmiana instytucjonalna może przyjać formę korekty, tj. mieć na celu przywrócenie lub zachowanie funkcji regulacji zatrudnienia - ochronnej lub koordynacyjnej - w sytuacji, w której instytucja wykazywałaby się pewnymi słabościami. Zmiana taka może w szczególności służyć dostosowaniu prawa do przemian instytucjonalnych lub ekonomicznych w celu przeciwdziałaniu zjawiskom postrzeganym jako zagrożenia dla spójności instytucjonalnej modelu. W ten sposób opisywane jest wprowadzanie modelu flexicurity w Danii w latach dziewięćdziesiątych. Polegało ono na jednoczesnym uelastycznieniu prawa pracy (postrzeganego jako posiadajace funkcję ochronna), a skutki tych działań były łagodzone przez rozbudowę ochronnych instrumentów welfare state ${ }^{38}$. Flexicurity spełnia rolę dostosowania regulacji do zewnętrznych wobec prawa i nieuchronnych przemian. Podobnie opisywana - jako nakierowana na zachowanie funkcji koordynacyjnej prawa pracy ${ }^{39}$ - jest liberalizacja zasad zwalniania i funkcjonowania agencji zatrudnienia w Japonii w latach dziewięćdziesiątych. Również adaptacje dokonywane przez aktorów gospodarczych moga mieć na celu przywrócenie funkcji formalnych regulacji zatrudnienia. Gregory Jackson jako przykład takich korekcyjnych dostosowań pokazu-

\footnotetext{
35 Streeck, Thelen (2005).

36 Np. Starke (2006).

${ }_{37}$ Morgan, Whitley, Moen (2005); Streeck, Thelen (2005).

38 Thelen (2014): 140-149; Campbell, Pedersen (2007).

39 Vogel (2005).
} 
je przekształcenie sposobu funkcjonowania rad pracowniczych w Niemczech w latach dziewięćdziesiątych ${ }^{40}$. W części firm pracodawcy i pracownicy zaczęli wykorzystywać formalnie ugruntowaną instytucję rad pracowniczych w nieco inny sposób, aby negocjować w sposób bardziej elastyczny wynagrodzenia i warunki pracy. Miało to na celu ułatwienie koordynacji ekonomicznej, rozwój firm i poprawianie sytuacji pracowników w konkretnych zakładach pracy.

Po drugie, zmiana formalnych regulacji zatrudnienia może obejmować przekształcenie funkcji, jaka pełnią formalne regulacje zatrudnienia w szerszym porządku instytucjonalnym modelu gospodarczego - z ochronnej na koordynacyjna, i na odwrót. Zmiana prawa pracy może być instrumentem lub jednym z instrumentów planowanej przez rząd transformacji modelu instytucjonalnego. Reformy są widziane zwykle jako elementy szerszych przekształceń, wiążących się z modyfikacją funkcji regulacji zatrudnienia. Przebiega to przez zmianę funkcji z ochronnej na koordynacyjna, najczęściej przez uelastycznienie i liberalizację ${ }^{41}$.

Ten sposób rozumienia był implicite zawarty jeszcze we względnie statycznych opisach modeli instytucjonalnych koncentrujących się na funkcjach poszczególnych instytucji, w tym prawa pracy. Elementy dynamiki zmian instytucjonalnych zachodzacych wokół formalnych regulacji zatrudnienia traktowane były w kategoriach zagrożeń dla układu instytucjonalnego traktowanego jako pewna spójna całość. W zakresie reformy prawa pracy - w szczególności jego etatyzacja rozumiana jako rosnące znaczenie indywidualnego prawa pracy - były uznawane za symptom słabnącej organizacji świata pracy i obniżającej się spójności wariantów instytucjonalnych. W społeczeństwach, w których pracownicy nie są w stanie zorganizować się w silne związki zawodowe (blokujące niekorzystne dla pracowników reformy), nie ma również szans na to, żeby w toku transformacji modelu instytucjonalnego zostały wdrożone zmiany propracownicze. W związku z tym na przykład rosnąca rola legislacji w angielskim ${ }^{42}$, francuskim ${ }^{43}$ czy niemieckim ${ }^{44}$ modelu relacji pracownikpracodawca jest postrzegana jako element erozji stosunków przemysłowych i przechodzenia z modelu kooperacyjnego na bardziej rynkowy.

Przyglądając się problemowi dokładniej: liberalizacja prawa pracy w latach osiemdziesiątych i dziewięćdziesiątych we Francji jest opisywana jako jeden z elementów reformy mającej przekształcić francuski model gospodarczy dirigiste, zakładający kontrolowanie przez państwo kluczowych sektorów gospodarki przez wielkie publiczne firmy oraz silnie protekcyjny charakter regulacji zatrudnienia. Nowy wariant gospodarczy miał mieć bardziej elastyczny rynek pracy, bliższy anglosaskiemu rynek produktowy oraz opierać się na silniejszym wspieraniu małych i średnich przedsiębiorstw. Funkcja ochronna prawa pracy miała zostać porzucona na rzecz funkcji koordynacyjnej, zadania

\footnotetext{
40 Jackson (2005).

41 Baccaro, Howell (2011).

42 Schmidt (2002): $163 \mathrm{n}$.

43 Schmidt (2002): 82.

${ }_{44}$ Thelen (2014); Martin (2014).
} 
ochronne zaś miało przejaćć bardziej rozbudowane welfare state ${ }^{45}$. Innego przykładu dostarczają opisy deregulacji amerykańskiej gospodarki, gdzie ograniczenie uprawnień związków zawodowych i liberalizacja prawa pracy z drugiej połowy lat siedemdziesiątych i lat osiemdziesiątych miały na celu porzucenie protekcyjnego modelu regulacji zatrudnienia na rzecz modelu realizujacego założenia neoliberalne, w którym regulacje zatrudnienia realizują wyłącznie funkcje koordynacji ekonomicznej ${ }^{46}$. Wreszcie, uważniejsze przyjrzenie się problemowi zmiany instytucjonalnej przez badaczy wykorzystujących perspektywę VoC pozwoliło dostrzec, że zmiany mogą być również zainicjowane przez aktorów społecznych. Specyficzna dla Niemiec forma liberalizacji rynku pracy zachodząca jeszcze od lat osiemdziesiątych, polegająca na powstawaniu dualnego rynku pracy z segmentem pracowników znajdujacych się poza ochroną związków zawodowych i standardowego zatrudnienia, przebiega przez proces wykorzystywania nietypowych umów o pracę w sektorach, gdzie związi zawodowe były słabe ${ }^{47}$. Traktując regulacje zatrudnienia jako narzędzia koordynacji ekonomicznej, a nie instrumentu ochrony pracowników, aktorzy gospodarczy przyczyniali się do erozji niemieckiego modelu relacji pracowniczych i głębokich przekształceń całego modelu instytucjonalnego gospodarki koordynowanej ${ }^{48}$.

Literatura wykorzystująca perspektywę VoC skoncentrowana na zagadnieniu stopniowej zmiany instytucjonalnej dostrzega więc dwoistość funkcji, jakie mogą realizować formalne regulacje zatrudnienia. Należy również zauważyć, że w obrębie tej literatury duży nacisk kładzie się na podmioty inicjujące zmianę. Inicjatorami takimi mogą być, oprócz rządu, także aktorzy społeczni wykorzystujący dane instytucje (np. przez adaptowanie ich do nowych zastosowań).

\section{PODSUMOWANIE}

Powracajacym problemem w literaturze $\mathrm{VoC} \mathrm{w}$ zakresie formalnych regulacji zatrudnienia jest zagadnienie funkcji, jaką regulacje te pełnią w szerszym porządku instytucjonalnym. Aby wyjaśnić zróżnicowanie między badaczami, musimy się więc zastanowić, w jaki sposób odnoszą się do funkcji samego formalnego porządku instytucjonalnego w odniesieniu do systemu gospodarczego. Fred Block zauważył, że choć badacze wykorzystujący VoC bardzo wiele mówili o różnicach pomiędzy poszczególnymi modelami gospodarczymi, to założenia podejścia - w szczególności zaś samo pojęcie kapitalizmu - często pozostawały niewysłowione lub wręcz ukryte ${ }^{49}$. W moim przekonaniu różnice w podejściu do analizy regulacji zatrudnienia sa związane z odmiennym rozu-

\footnotetext{
45 Levy (2005): 106-107.

46 Thelen (2014): 37-47.

47 Eichhorst, Marx (2011).

48 Streeck (2009): 149 n.

49 Block (2012): 273.
} 
mieniem istoty tego, czego dotyczy typologizowane „zróżnicowanie” - to znaczy właśnie „kapitalizmu”.

Badacze dostrzegający ekonomiczną funkcję regulacji zatrudnienia koncentrują się na gospodarczym wymiarze zróżnicowania kapitalizmu. Związane jest to z rozumieniem kapitalizmu przede wszystkim jako systemu produkcji i wymiany dóbr. Stąd też punkt ciężkości analizy koncentruje się na sposobie, w jaki zorganizowana jest produkcja, i problemach koordynacyjnych, które sa z tym związane. Typologizowane modele sa klasyfikowane przede wszystkim właśnie pod kątem różnic w tym zakresie. Formalne regulacje zatrudnienia sa tutaj widziane jako narzędzia służące do koordynacji działań ekonomicznych w zakresie współpracy między pracodawcami a pracownikami.

Rozbieżne rozumienie roli formalnych regulacji zatrudnienia jako realizujących przede wszystkim funkcję ochronną związane jest $\mathrm{z}$ innym pojmowaniem tego, czym jest „kapitalizm” 50 . Badacze ci widza kapitalizm jako system społeczno-gospodarczy, który moglibyśmy porównać do Polanyiowskiego „społeczeństwa rynkowego", gdzie instytucje promujące logikę rynkową są zakorzeniane w tkance społecznej i wartościach podzielanych przez społeczeństwo ${ }^{51}$. Zdaniem autora Wielkiej transformacji, projekt przekształcenia wszystkich relacji społecznych na wzór wymiany rynkowej napotyka opór ze strony społeczeństwa. Społeczeństwo oraz koncepcja gospodarki opartej na swobodnej wymianie dóbr i usług znajduja się w konflikcie, który rozwiązywany jest przede wszystkim przez tworzenie rozwiązań regulacyjnych nakładających ograniczenia na ekspansywny rynek. Polanyi nazywa to „dwukierunkowym ruchem", w którym rozszerzanie zakresu samoregulującego się rynku napotyka przeciwdziałanie w postaci wydzielania sfer i tworzących mechanizmy ograniczające logikę rynkowa ${ }^{52}$. Takie rozwiązania, które - wzorem późniejszej literatury - moglibyśmy nazwać dekomodyfikującymi, łagodzą konflikty interesów i pozwalaja gospodarce rynkowej funkcjonować. Poza polityką społeczną wyrażaną przede wszystkim przez państwo dobrobytu do tego rodzaju mechanizmów należą również formalne regulacje zatrudnienia, które ingeruja w nierówne w sensie faktycznym relacje między pracodawcą a pracownikiem.

Dwa sposoby spojrzenia na prawo pracy, pojawiające się w perspektywie VoC, wynikają więc z odmiennych sposobów rozumienia roli formalnego prawa i instytucji w obrębie samego porządku gospodarczego. Instytucje można widzieć albo jako formalną nadbudowę ułatwiająca koordynację ekonomiczna, albo wręcz przeciwnie - jako przejaw chęci ograniczenia ekspansji logiki rynkowej.

Karol Muszyński

Uniwersytet Warszawski

k.muszynski@wpia.uw.edu.pl

https://orcid.org/0000-0003-1697-0485

\footnotetext{
50 Spójrz równiez: Hodgson (2016).

51 Polanyi (2010): 239-247; 265-279.

52 Polanyi (2010): 157-158.
} 
Amable, B. (2003). The Diversity of Modern Capitalism. Oxford.

Baccaro, L., Howell, C. (2011). A common neoliberal trajectory: the transformation of industrial relations in advanced capitalism. Politics and Society 39(4): 521-563.

Becker, U. (2009). Open Varieties of Capitalism. Continuity, Change and Performances. LondonNew York.

Block, F. (2012). Varieties of what? Should we still be using the concept of capitalism? [w:] J. Go (ed.), Political Power and Social Theory (Political Power and Social Theory 23). Emerald Group Publishing Limited: 269-291.

Boyer, R. (1979). Wage formation in historical perspective: the French experience. Cambridge Journal of Economics 3(2): 99-118.

Boyer, R. (2005). How and why capitalisms differ. Economy and Society 34(4): 509-557.

Campbell, J.L., Pedersen, O.K. (2007). The varieties of capitalism and hybrid success: Denmark in the global economy. Comparative Political Studies 40(3): 307-332.

Coates, D. (2000). Models of Capitalism: Growth and Stagnation in the Modern Era. Cambridge.

Coates, D. (2015). Varieties of capitalism and 'the great moderation', [w:] M. Ebenau, I. Bruff, C. May (eds.), New Directions in Comparative Capitalisms Research. London: 11-27.

Crouch, C. (2005). Capitalist Diversity and Change: Recombinant Governance and Institutional Entrepreneurs. Oxford.

Hall, P.A., Gingerich, D. (2009). Varieties of capitalism and institutional complementarities in the political economy: an empirical analysis. British Journal of Political Science 39(3): 449-482.

Hall, P.A., Soskice, D. (2001). An introduction to varieties of capitalism, [w:] P.A. Hall, D. Soskice (eds.), Varieties of Capitalism: The Institutional Foundations of Comparative Advantage. Oxford: 1-68.

Hall, P.A., Thelen, K. (2009). Institutional change in varieties of capitalism. Socio-Economic Review 7(1): 7-34.

Hodgson, G.M. (2016). Varieties of capitalism: some philosophical and historical considerations. Cambridge Journal of Economics 40(3): 941-960.

Deeg, R., Jackson, G. (2006). Towards a more dynamic theory of capitalist variety. Socio-Economic Review 5(1): 149-179.

Dibben, P., Williams, C.C. (2012). Varieties of capitalism and employment relations: informally dominated market economies. Industrial Relations: A Journal of Economy and Society 51(1): $563-582$.

Ebbinghaus, B. (2006). Reforming Early Retirement in Europe, Japan and the USA. New York.

Eichhorst, W., Marx, P. (2011). Reforming German labour market institutions: a dual path to flexibility. Journal of European Social Policy 21(1): 73-87.

Emmenegger, P. (2011). Job security regulations in Western democracies: a fuzzy set analysis. European Journal of Political Research 50(3): 336-364.

Freeman, R.B. (2005). Labour market institutions without blinders: the debate over flexibility and labour market performance. International Economic Journal 19(2): 129-145.

Jackson, G. (2005). Contested boundaries: ambiguity and creativity in the evolution of German codetermination, [w:] W. Streeck, K. Thelen (eds.), Beyond Continuity: Explorations in the Dynamics of Advanced Political Economies. Oxford: 229-254.

Jackson, G., Deeg, R. (2008). Comparing capitalisms: understanding institutional diversity and its implications for international business. Journal of International Business Studies 39(4): $540-561$.

Jasiecki, K. (2014). Polska transformacja w perspektywie różnorodności kapitalizmu. Przegląd Socjologiczny 63(4): 45-66.

Katznelson, I., Weingast, B.R. (2005). Intersections between historical and rational choice institutionalism, [w:] I. Katznelson, B.R. Weingast (eds.), Preferences and Situations: Points of Intersection Between Historical and Rational Choice Institutionalism. New York: 1-26.

Korpi, W. (2006). Power resources and employer-centered approaches in explanations of welfare states and varieties of capitalism: protagonists, consenters, and antagonists. World Politics 58(2): 167-206.

Levy, J.D. (2005). Redeploying the state: liberalization and social policy in France, [w:] W. Streeck, K. Thelen (eds.), Beyond Continuity: Explorations in the Dynamics of Advanced Political Economies. Oxford: 103-126. 
Maszczyk, P. (2015). Ewolucja modelu kapitalizmu w Polsce. Nierówności Społeczne a Wzrost Gospodarczy 41: 107-122.

Marsden, D. (1999). A Theory of Employment Systems: Micro-Foundations of Societal Diversity. Oxford.

Martin, J. (2014). Getting down to business: varieties of capitalism and employment relations, [w:] A. Wilkinson, G. Wood, R. Deeg (eds.), The Oxford Handbook of Employment Relations: Comparative Employment Systems. Oxford: 65-85.

Michelotti, M., Nyland, C. (2008). Varieties of capitalism and diversity in labour standards regulation: the case of Italy. European Journal of Industrial Relations 14(2): 177-195.

Morgan, G., Whitley, R., Moen, E. (eds.) (2005). Changing Capitalisms? Institutional Change and Systems of Economic Organization. Oxford.

Nölke, A., Vliegenthart, A. (2009). Enlarging the varieties of capitalism: the emergence of dependent market economies in East Central Europe. World Politics 61(4): 670-702.

Polanyi, K. (2010). Wielka transformacja. Tłum. M. Zawadzka. Warszawa.

Próchniak, M. et al. (2016). The emerging models of capitalism in CEE11 countries - a tentative comparison with Western Europe. Warsaw Forum of Economic Sociology 7(2): 7-70.

Restrepo Amariles, D. (2015). Legal indicators, global law and legal pluralism: an introduction. The Journal of Legal Pluralism and Unofficial Law 47(1): 9-21.

Schmidt, V.A. (2002). The Futures of European Capitalism. Oxford.

Screpanti, E. (2017). Karl Marx on Wage Labor: From Natural Abstraction to Formal Subsumption. Rethinking Marxism 29(4): 511-537.

Soskice, D. (2009). Varieties of capitalism, varieties of reform, [w:] A. Hemerijck, B. Knapen, E. van Doorne (eds.), Aftershocks: Economic Crisis and Institutional Choice. Amsterdam: 133-141.

Starke, P. (2006). The politics of welfare state retrenchment: a literature review. Social Policy and Administration 40(1): 104-120.

Streeck, W. (2009). Re-Forming Capitalism: Institutional Change in the German Political Economy. Oxford.

Streeck, W. (2011). E pluribus unum? Varieties and commonalities of capitalism, [w:] M. Granovetter, R. Swedberg (eds.), The Sociology of Economic Life. Boulder-Oxford: 419-455.

Streeck, W. (2015). The Crisis in Context Democratic Capitalism and Its Contradictions. Köln.

Streeck, W., Thelen, K. (2005). Introduction: institutional change in advanced political economies, [w:] W. Streeck, K. Thelen (eds.), Beyond Continuity: Explorations in the Dynamics of Advanced Political Economies. Oxford: 1-39.

Thelen, K. (2004). How Institutions Evolve: The Political Economy of Skills in Germany, Britain, the United States and Japan. Cambridge.

Thelen, K. (2014). Varieties of liberalization and the new politics of social solidarity. New York.

Thompson, E.P. (1971). The moral economy of the English crowd in the eighteenth century. Past and Present 50(1): 76-136.

Vogel, S.K. (2005). Routine adjustment, bounded innovation, [w:] W. Streeck, K. Thelen (eds.), Beyond Continuity: Explorations in the Dynamics of Advanced Political Economies. Oxford: $145-168$.

Whitley, R. (1999). Divergent capitalisms: the social structuring and change of business systems. Oxford.

Whitley, R. (2007). Business systems and organizational capabilities: the institutional structuring of competitive competences. Oxford.

Williamson, O. (1975). Markets and Hierarchies. New York.

Witt, M.A., Jackson, G. (2016). Varieties of Capitalism and institutional comparative advantage: a test and reinterpretation. Journal of International Business Studies 47(7): 778-806.

Wojtyna, A. (2005). Alternatywne modele kapitalizmu. Gospodarka Narodowa 9(169): 1-23. 


\section{FORMAL REGULATION OF EMPLOYMENT IN VARIETIES OF CAPITALISM}

\section{Summary}

This paper analyses how the role of formal employment regulations (labour law) is described in the propositions of researchers who use the varieties of capitalism perspective (VoC). VoC is paradigmatic in comparative research on capitalism. The paper presents the different approaches to the role of regulations that intervene in the relations between employers and employees. Some researchers ignore formal employment regulations and focus on larger units of analysis. The next group of researchers is more focused on comparing systems of production in different states and concentrates on the economic function of labour law. Researchers who combine economic analyses with research on the welfare state treat employment regulation as a supplement or substitute for the instruments of the welfare state. Finally, research focused on the issue of institutional change tends to integrate both functional approaches and treats formal employment regulations from the point of view of institutional coherence, manifesting a specific, identified function. The paper argues that the conceptualization of the role of formal employment regulations depends on the way one understands the role of formal law and institutions within the economic order. Institutions can be seen either as a formal 'superstructure' that eases economic coordination, or as a manifestation of the will to limit the expansion of market logic.

Keywords: varieties of capitalism; new institutionalism; labour law; employment regulation; welfare state 
